\title{
Power engineering in agriculture and its efficiency
}

Aziza Demessinova*, Zhamilya Kydyrova, Tofik Aydarov, Gulnara Moldogaziyeva, Marzhan Daurbayeva, Indira Kozhamkulova, Dilyara Zhakipbekova

Department of Management and Marketing, South Kazakhstan State University Named After M. Auezov, Shymkent, Republic of Kazakhstan

\section{A R T I C L E I N F O}

\section{Article history:}

Received 21 September 2017

Received in revised form

28 December 2017

Accepted 28 December 2017

\section{Keywords:}

Agrarian economy

Energy security

Rural power engineering

Renewable energy sources

Power efficiency

\begin{abstract}
A B S T R A C T
During the exacerbation of global economic problems, the development of renewable power engineering has been gaining traction. In the next decade, this trend will not only persist, but also increase its dynamics, primarily due to the increasing frequency of multifactorial global crises in power engineering. Consideration of all factors, including natural and climatic ones, will ensure the energy security of the region. In this study, we focus on climate change as one of the main threats to the development of renewable power engineering in Kazakhstan. Power engineering is a strategic branch of Kazakhstan's economy, the foundation of the functioning of all economic spheres and the population, which generates a considerable share of the budgetary revenue of the country. Energy source shortage in rural areas is a serious disadvantage for the development of the economy. This necessitates the development of bio- and geothermal power engineering, with a view to supplying enough power to the rural areas of the South Kazakhstan Region of the Republic of Kazakhstan.
\end{abstract}

(C) 2017 The Authors. Published by IASE. This is an open access article under the CC BY-NC-ND license (http://creativecommons.org/licenses/by-nc-nd/4.0/).

\section{Introduction}

Nowadays, new trends are emerging in the global agrarian economy and demography; integrative processes are developing actively; global climate changes are occurring. Kazakhstan has joined the Eurasian Customs Union (EACU). In July of 2017, Kazakhstan joined the World Trade Organization (WTO). However, the poor level of labor effectiveness in the industry, flawed technologies, small-scale production, and flawed rural power engineering do not allow running agricultural production on an intensive basis, ensuring the fullest utilization of material, labor, and other resources, and meeting environmental requirements. These factors undermine the competitiveness of the Kazakh agrarian industry, which, in the conditions of the WTO and the EACU, can lead to the dominance of imported foreign products on the market and force local domestic producers out of the sales markets.

The population of the country grows, as does the rate of consumption of food; the structure of consumption is shifting towards higher-quality products. The role of agriculture in the country's

\footnotetext{
* Corresponding Author.

Email Address: ademessinova@yahoo.com (A. Demessinova) https://doi.org/10.21833/ijaas.2018.03.003

2313-626X/C 2017 The Authors. Published by IASE.

This is an open access article under the CC BY-NC-ND license

(http://creativecommons.org/licenses/by-nc-nd/4.0/)
}

food supply, employment, and economic development is increasing.

Power supply to rural areas that host economic entities has become one of the main research subjects for many prominent contemporary scientists and politicians. Researchers have analyzed the current need for energy resources with regard to the trends of socioeconomic development of regions and developed scenarios of development of the power engineering industry up to 2030 and 2050; in addition, they researchers various sources of their investment (Grechukhina and Kiryushin, 2015; Kiushkina, 2016; Energy Outlook 2030, 2011). Kiushkina (2016) examined the trends in the utilization of various energy resources. Her analysis showed that the trends in the modern development of world power engineering were multidirectional.

In the long run, the development of the world economy and power engineering is determined by various scenarios and forecasts, which are given in multiple information and scientific sources and works of analysts, experts, and companies. Some points in these scenarios and forecasts are different, but most of them have common points and opinions. According to experts of many companies, the predictive assessments are associated with risks and uncertainty, since they are related to events and circumstances that may emerge in the future - actual results can differ from estimated ones and depend on various factors: product supply, demand, and 
pricing, political stability, general economic conditions, changes in legal and regulatory acts, availability of cutting-edge technologies, climate change, etc. The initial groundwork in the long-term strategy that was developed by experts of ExxonMobil is the Energy Outlook 2030. Its main parameter is the increase in the global energy demand by $60 \%$ versus 2000 . Oil, gas, and coal will remain the main sources of energy. Demand for gas and coal will grow faster than that for oil due to the stimulation of the development of electric power engineering. Coal will be the leader in terms of the growth of generating capacity, followed by gas and hydropower with renewable sources, while nuclear power will play a minor role. Gas and renewable energy sources will be the "winners" of the development trend in world power engineering as the shares of various types of fuel even out.

The current development of world power engineering is determined by multidirectional trends: the development of power generation and transportation technologies, increase in the share of renewable energy sources, and improvement of power-saving technologies on the one hand and rapid energy source price hikes and increasing public awareness of the environmental problems of power engineering on the other hand (Ferroukhi et al., 2013).

Scientists have drawn a map that shows renewable energy sources in 139 countries (Kateneva, 2016). According to them, a global transition to renewable energy sources would help create 20 million jobs, which would compensate for the economic losses in the nonrenewable energy source sector. In recent years, researchers have acknowledged the urgent need to design new technologies of production and utilization of power that require cheaper and more efficient power plants. Scientists admit that the abandonment of hydrocarbons will be protested against by politicians and representatives of the businesses involved. They believe that the transition to renewable power engineering is necessary and practically possible, considering the resource potential (natural, climatic, raw material, human, innovative, etc.) of the global economy.

In recent years, the cost of production of "green" power continues to decrease, which is why the prediction of American scientists no longer seem as fantastic as they used to (Farrell, 2009; Mitchell et al., 2011; Verbruggen and Lauber, 2012). From 2008 to 2016 , the cost of power generated by wind farms has dropped by $41 \%$, while that of solar power had dropped by $54 \%$.

Scientists evaluate alternative technologies of generation and distribution of power from the perspective of their safety, affordability, and environmental stability. They propose this or that type of renewable energy source or complexes thereof with regard to natural, climatic, geographic, and economic characteristics of the development of their country. By 2050, many countries plan to meet more than half of the demand for power via renewable energy sources. However, many researchers do not take into account the trends in the changes of factors that affect the development of power engineering (Jenner et al., 2013; Rutovitz and Harris, 2012). For instance, the continuously increasing global warming can affect the development of wind power, hydroelectric power, and bioenergy. Based on the predictions of environmentalists regarding climate change, it is possible to assume that renewable energy sources may become nonrenewable in the foreseeable future.

Therefore, when predicting and planning the development of renewable power engineering, it is necessary to take into consideration the trends in the development of all factors that affect its development. Scientists from all around the world should unite to solve environmental problems and establish international "environmental foundations" that would implement environmental programs on a global scale, since climate change is a global phenomenon. Flawless information technologies should be used to achieve accurate forecasts, figure out the trends in the changes of factors that affect the development of power engineering, and develop plans to take appropriate measures. Much depends on the politicians' stance on the resolution of these problems. In the twenty-first century, many scientists and politicians consider renewable energy sources as the main source of power of the future (De Jager et al., 2008; McCollum et al., 2011). One of the proofs of increased attention of researchers and businesses to the development of renewable energy sources is their participation in EXPO-2017, held in June-September in Astana.

It is necessary to simultaneously develop "green" technologies of power generation that would be independent from exhaustible natural resources. For instance, electric power generation based on the magnetic field of permanent magnets, sand, living trees, physical motion of humans or animals, heatinsulating coating that is capable of generating electric power from the difference between the temperature of building walls and that of the environment, etc. These technologies have yet to become widespread, but they can be regarded as "green" technologies of power generation that utilize inexhaustible natural resources. These energy technologies are not mentioned in a single energy program of any country; however, they do exist and require further improvement and investment support from the state and businesses.

Unfortunately, renewable power engineering is underdeveloped in Kazakhstan, which is why fundamental studies on its development are few and far between. This is because renewable power engineering in Kazakhstan has not yet become a fullfledged branch of power engineering. Therefore, the Kazakh sector of renewable energy sources as a research object requires special attention from both the government and business.

The efficient use of electric energy in agriculture has been considered in Kazakh scientific literature up to this point within the framework of the 
command and administration system, wherein the functioning of commodity-money relations is limited. A deformed system of planning, crediting, and taxing of agricultural companies caused low rates of development of agriculture and a chronic food shortage in the country. In such conditions, most agrarian companies were unprofitable or marginally profitable and operated at the expense of budgetary allocations and grants.

Market relations require new approaches to this problem and set new goals and tasks for the further expansion of the area of application and rational utilization of electric energy in agriculture.

The purpose of this research is to propose ways of improving the energy security of agriculture in the region with regard to the peculiarities of electric energy utilization in this field.

The research subjects are alternative variants of generation and distribution of electric energy in the rural area of the region.

The research object is the rural area of the South Kazakhstan Region, Republic of Kazakhstan.

\section{Theoretical and methodological framework}

The research is based on theoretical and methodological principles that have been described in the works of classical authors of economics and management, as well as the works of contemporary
Kazakh and foreign researchers in the field market economy. The sources of information included Manifestoes of the Government of the Republic of Kazakhstan, materials of the Ministry of Agriculture of the Republic of Kazakhstan and the Committee on Statistics of the Ministry of National Economy of the Republic of Kazakhstan, regulatory documents, recommendations of research and development institutions, as well as personal observations of the authors of this paper.

\section{Results}

A new industry-specific program for the development of the agricultural sector of the Republic of Kazakhstan has been developed due to the changing conditions in the external and internal environments caused by Kazakhstan joining the EACU and the WTO and the need to use new instruments of state regulation and modernization of the industry.

The development of agriculture in Kazakhstan is characterized by the following trend: the gross output of agriculture tends to grow from 1641352.40 million tenge (currency of Kazakhstan) in 2009 to 2386103.50 million tenge in 2015 (Table 1 and Fig. 1). Average annual growth rate of agricultural products over the last five years was $109.2 \%$.

Table 1: Dynamics of electric power consumption by agriculture in the Republic of Kazakhstan

\begin{tabular}{|c|c|c|c|c|c|c|}
\hline \multirow{2}{*}{ Indicator } & \multirow{2}{*}{ Unit of measurement } & \multicolumn{5}{|c|}{ Year } \\
\hline & & 2011 & 2012 & 2013 & 2014 & 2015 \\
\hline $\begin{array}{l}\text { Gross output of agriculture (in constant } \\
\text { prices) }\end{array}$ & million tenge & 1641352.4 & 1442630.1 & 2286042.3 & 1999046.6 & 2386103.5 \\
\hline Total energy consumed & million kWh & 63049.40 & 64955.60 & 61887.86 & 62832.80 & 64406.80 \\
\hline Energy consumed by agriculture & million kWh & 819.6422 & 779.4672 & 1547.1965 & 1460.4724 & 1631.3475 \\
\hline
\end{tabular}

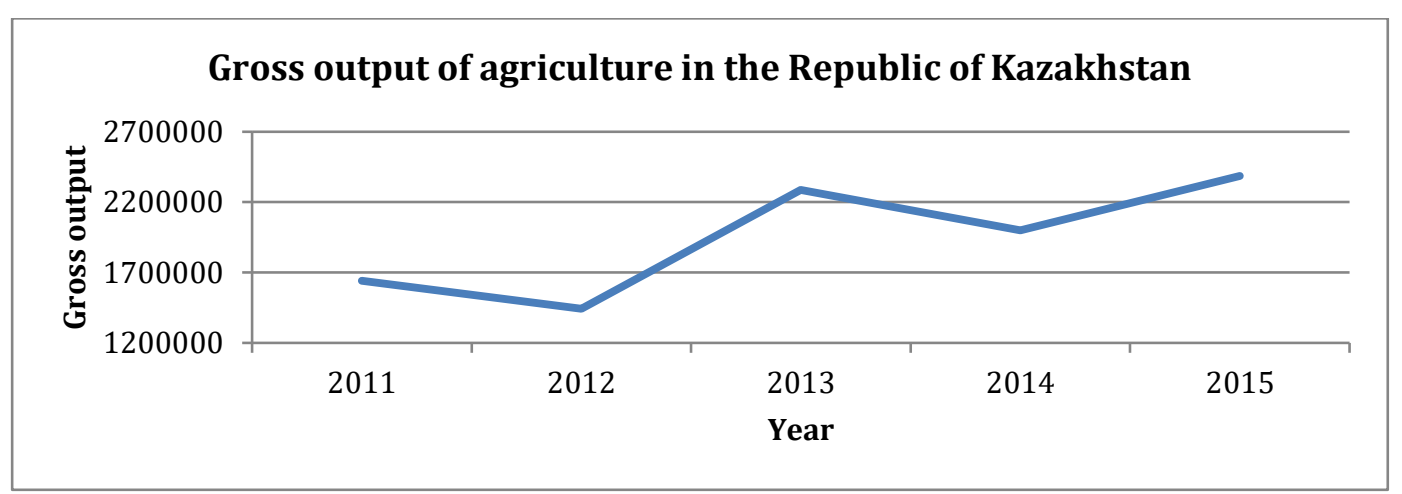

Fig. 1: Gross output of agriculture (in constant prices), million tenge

Studies on agriculture showed that one of the factors that affects the growth of the gross output of agriculture was energy consumption.

The following equation demonstrates the dependency of the gross output of agriculture on the electric energy consumed by agriculture:

$Y=770025.4+946.6 * \mathrm{x} 1$,

where $\mathrm{Y}$ is the gross output of agriculture (in constant prices), million tenge; $\mathrm{x} 1$ is the energy consumed by agriculture, million kWh.
The equation shows that an increase in the power consumption rate in agriculture by $1 \mathrm{kWh}$ increases the gross output of agriculture by 946.6 tenge.

Many contemporary studies cover the problem of energy security. Energy security has many aspects to it, but a universal definition of this concept is still lacking. The most general definition is that energy security is the state of protection in the aspect of prospects of development of national and global power engineering.

For most economic entities that are located in the southern region of the Republic of Kazakhstan, most 
of the demand for electric energy is satisfied by supply from the outside. The unresolved problems in this field can become a real threat to the energy security of this region in the near future. Therefore, ensuring stable power supply to even the smallest rural settlements is regarded as an energy security issue.

The main goal of rural electric power engineering is to ensure the progressive development of production capacities, improve the efficiency of production in the agrarian sector of the economy, and create the necessary living and social conditions in rural areas.

In order to detect the trends and predict the development of rural power engineering, it is necessary to assess the threats to energy security, because this knowledge will enable taking timely measures, with a view to preventing and avoiding the most probable issues.

One can distinguish five types of threat to energy security: economic; technical; managerial and legal; sociopolitical; natural-climatic. The most significant ones are economic and natural-climatic threats. The levels of energy security can be analyzed and assessed via indicative analysis, which allows solving the problems of functioning of large social, technical, and economic systems, which includes the energy system. These systems are characterized by diverse properties, parameters, complex internal and external connections, and uncertain states and conditions of development. The current state of energy systems, the dynamics of changes in the state of the systems during a retrospective period, and the estimated development within a forecasted timeframe can be determined based on indicators. The assessment of energy security in general and this or that indicator thereof in particular is conducted by comparing the values of indicators to the indicators of threshold (boundary) levels. Depending on the impact of regulatory factors, the energy system can be in one of four qualitative states: normal, pre-critical, critical, and post-critical.

Inefficient use of energy resources increases the cost of agricultural products. The prime cost of agricultural products consists of power costs by more than a half. Agricultural products cannot be competitive with the current prices of fuel and energy. In such conditions, the main emphasis should be placed on the implementation of tools for the electrification and automation of agricultural production, which requires an appropriate state of the power-grid facilities, with a view to ensuring reliable power supply to the consumer - the agricultural producers.

In agriculture, electric power is used for different causes: to heat greenhouses, set in motion new improved production mechanisms, to conduct electric machine irrigation. In addition, electric power is used in agricultural processes that utilize radio-frequency currents, ultraviolet and infrared rays, ultrasound, etc. Household use of electric power brings the living conditions in rural areas closer to those in cities.
The role and significance of agricultural electrification increase considerably due to the task of improvement of its effectiveness.

Nowadays, prerequisites exist to transform agriculture into a highly effective industry. Mechanization and electrification of agriculture and reclamation of thousands of hectares of virgin and fallow land have had a positive impact on the growth of the output of agriculture, which, in turn, improved the supply of agricultural products to the rapidly growing urban population and the supply of raw material to processing facilities. Mechanization and electrification of agriculture increase the need for energy resources. Further electrification of agricultural production is a crucial condition for the technological progress in Kazakhstan.

One of the prerequisites for the successful development of the regional agricultural sector is the improvement of the system of power supply to agricultural producers through the construction of new and reconstruction and modernization of existing electric networks of centralized power supply. In turn, the development of rural electric power engineering is a prerequisite for the maintenance of the optimal level of national and economic security of the region.

Power supply to consumers can use three options: decentralized, centralized, and mixed. The main arguments against centralized power supply to rural areas and remote consumers are its unprofitability due to the high cost of power lines and low consumption capacities.

At that, the problem of power supply is solved based not on the capacities of the big generation center, but on the consumption location, the interests of specific consumers, the availability of resources, and other possibilities. Therefore, the area of application is determined specifically: power zones (a counterpart of foreign insular energy systems) and weak points of networks that require additional capacities. In European countries, this variant of power supply is regarded as an important strategic direction. Practice shows that decentralized energy systems can be a profitable area for investment if said systems are capable of simultaneously generating thermal energy and placing the source of energy generation near consumers. The power transfer costs usually constitute almost $30 \%$ of its production cost, while heat generation adds $20-40 \%$ of profit.

The existing methods of design of remote consumer power supply system's usually regard power supply via the generation of electric power on the basis of renewable energy sources or the use of boilers or diesel generators that operate in monogeneration mode as an alternative to centralized power supply.

There is a real possibility to solve the problems of power supply to remote and difficult to access rural areas by using hybrid stations as energy sources.

The current state of development of agriculture requires shifting as soon as possible to new models of energy efficiency and power supply by improving 
the efficiency of primary fuel and energy resources, using secondary fuel and energy resources, renewable energy sources, as well as local and alternative fuel.

International organizations and national governments are paying more attention to the transition to a new economic model and "intellectual" agriculture as its integral part. "Intellectual" agriculture is based on the use of automated decision-making systems, comprehensive automation and robotization of production, and ecosystem design and modeling technologies (Cook, 2005). It implies the minimization of the use of external resources (fuel, fertilizers, and agricultural chemicals) and maximizing the involvement of local production factors (renewable energy sources, biofuel, organic fertilizers, etc.). Energy saving and improvement of energy efficiency should be managed by creating a special organizational and economic mechanism. The main goal of energy consumption management in production is to minimize consumption and rationalize energy utilization while maintaining appropriate output and product quality. Energy consumption management is a dynamic and systemic process of regulation of the level of consumption of energy resources, with a view to achieving the planned output of agricultural products while maintaining economically and technologically reasonable energy consumption levels. There are four directions of energy saving in agriculture:

- absolute cutting of the number of energy types consumed via rationalization of economic management methods, intensification, and implementation of energy- and resource-saving production technologies;

- replacement of expensive energy resources that are in short supply with resources that are more easily available;

- expansion of the area of application of nonconventional and renewable energy sources;

- change of the organization management system, creation and implementation of an organizational and economic energy-saving mechanism.

When developing these four directions, it is necessary to take into account the presence of both stimulating and inhibiting factors. This will allow finding problematic points in the development of the energy saving concept and making appropriate corrections. Stimulating factors include:

- development of a concessional lending system for the energy-saving measures of agricultural companies and farms;

- state support of the development of agriculture;

- implementation of cutting-edge and progressive technologies and scientific projects that suit the climate;

- development of special social-production programs that would allow designing a system of stimulation for the managers of agricultural companies and organizations, involvement of young specialists, state and regional support of implementation of cutting-edge technologies, etc. Inhibiting factors include:

- high cost of implementation of energy-efficient technologies;

- flawed mechanism of implementation of energyefficient technologies;

- shortage of personnel required to work with cutting-edge technologies;

- shortage of funding of production reformation;

- use of outdated production systems and mechanisms;

- lack of tax concessions and state support in the development of the agricultural sector;

- poor awareness of successful cases of implementation of cutting-edge technologies.

The solution of these problems should be considered on the national and regional levels; special systems of state support and monitoring should be developed. Any managerial decision should be analyzed subsequently and adjusted or canceled if it turns out to be ineffective. Mechanisms of management of energy resource utilization efficiency will enable accomplishing the set objectives within a short time. The stages of improvement of resource utilization efficiency are defined by the necessity to take such measures as to take a complex approach to the problem, develop a monitoring system for the functioning of the mechanism of efficient energy resource utilization, search for new concepts of improvement of energy resource utilization efficiency, design methods of energy consumption management at each stage of the technological process, develop a system of nonfinancial criteria for monitoring the activity of companies, and develop a set of measures for the improvement of the effectiveness of the implemented model. Organizational and technological measures imply an improvement of the production culture, adherence to rated duties, sorting out the energy economy, assurance of proper loading and utilization of devices, and timely adjustments and repairs (Sidorovich, 2015).

The combination of all these measures will enable utilizing resources with maximum efficiency and reducing the amount of power consumed by production.

In the current state of development of agriculture, new models of energy saving and improvement of energy efficiency should be implemented with an active use of renewable energy sources.

In recent years, the world has made a major step towards using renewable energy sources. According to the International Energy Agency (IEA), the growth rate of conventional coal and gas power engineering has been about $2 \%$ per annum since the start of the twenty-first century (including big hydraulic power engineering - 2\%, atomic power engineering - 
1.6\%). At the same time, the growth rate of wind and solar power engineering has been $25 \%$ and more for several years straight, which exceeds the growth rate of conventional power engineering significantly.

A crucial positive property of power engineering with renewable energy sources is the fact that its nodes and devices can be repaired using tools that can be found in the workshop of any mechanical engineering facility or even in an ordinary village workshop.

It is also necessary to use renewable energy source because the structure of formation of the prime cost and tariffs for centralized electric energy is such that if the prime cost of generation and distribution of power is taken as $100 \%$, its components by stages of formation will be as follows (Table 2).

Table 2: Structure of the prime cost and tariffs of electric power

\begin{tabular}{crc}
\hline Stage level & Prime cost by stages of its formation & yield,\% \\
\hline 1 & Electric power generation at base load power plants & 28 \\
2 & Transportation of electric power along backbone power lines & 5 \\
3 & Transportation and distribution of electric power among high-voltage networks & 14 \\
4 & Transportation and distribution of electric power among medium-voltage networks & 15 \\
5 & Transportation and distribution of electric power among low-voltage networks & 24 \\
6 & Technical accounting and settlement with consumers & 14 \\
& Total & 100 \\
\hline
\end{tabular}

Table 2 shows that the prime cost of electric power generation by power stations constitutes about $1 / 4$ of the total prime cost. This is caused by the fact that Kazakhstan mostly runs big and mediumsized heat power plants, combined heat and power plants, hydroelectric power stations, etc. with vast distribution networks (areas).

Agriculture in Kazakhstan consumes only 2.5$3.0 \%$ of the total amount of energy consumed. This makes the maintenance of rural power lines unprofitable.
In several regions of Kazakhstan, it is possible to bring electric power generation closer to rural areas by constructing small hydroelectric power stations, but this is not enough to meet the demand for electric power in full.

One of the factors that affect the development of rural electric power engineering is power supply that is achieved by using heat insulation of industrial and nonindustrial rural buildings that were constructed at the time when cheap energy sources were used. This would cut fuel consumption significantly (Table 3).

Table 3: Level of heat protection of rural buildings

\begin{tabular}{cccccc}
\hline Heat protection level, $\mathrm{kJ} /\left(\mathrm{m}^{2} \cdot \mathrm{K} \cdot \mathrm{day}\right)$ & 270 & 380 & 420 & 650 & 1200 \\
\hline Percentage of buildings & 0.07 & 0.18 & 0.38 & 0.18 & 0.08 \\
\hline
\end{tabular}

The table shows that the specific rate of heat energy consumption for heating in the rural area exceeds modern standards by two-five times. Furthermore, fuel supply to remote settlements comes with increased financial and material expenses.

Modern practice shows that the strategic development of the fuel and energy complex of any region should be connected with the use of renewable energy sources and fuel and energy resources.

The use of so-called "green" technologies becomes especially relevant.

"Green" power stations use renewable energy sources, such as the Sun, wind, and hydraulic energy, which generate environmentally friendly electric power. Solar and wind power stations are currently incapable of competing with nuclear power and high-capacity power plants. However, "green" stations already have their niche in global power engineering. The leaders in power engineering based on renewable energy sources are Eastern and Southeastern Asian countries, probably due to the favorable combination of natural, resource, and economic prerequisites. In particular, the share of China in the global manufacturing of solar batteries exceeded $60 \%$ in 2014; in terms of this product, China dominates not only the Asian market, but also the European market while forcing out local manufacturers. China holds the first place in the world in terms of the number of installed wind farms, while also holding a leading position in terms of the growth rate of power engineering based on renewable energy sources.

Kazakhstan has all the natural conditions required to develop solar, bio-, and wind power engineering. However, nowadays, the percentage of renewable energy sources does not exceed $0.2 \%$ of the total electric power output. Wind power engineering in Kazakhstan is underdeveloped, is spite of the existence of necessary natural conditions. For instance, wind speed near the Dzungarian Gate and the Shelek Corridor ranges from 5 to $9 \mathrm{~m} / \mathrm{s}$. In December of 2011, the first wind farm in Kazakhstan - the Kordanay Wind Farm (first stage) with a capacity of $21 \mathrm{MW}$ - was launched in the Jambyl Region. In December of 2014, the first stage of the nine wind generations was constructed, which increased the capacity by 9 MW. In addition, the construction of a second wind farm with a capacity of $21 \mathrm{MW}$ is nearing completion in the Korday District. The construction of the Ereymentau wind farm with a capacity of $45 \mathrm{MW}$ started in October of 2013. The implementation of projects for the Zhanatas wind farm with a capacity of up to 400 MW (Jambyl Region) and the Shokpar wind farm 
with a capacity of 200 MW (Jambyl Region) has begun.

The utilization of solar power in Kazakhstan is also insignificant, despite the fact that the annual sunlight duration is 2200-3000 hours per annum, while the estimated capacity is $1300-1800 \mathrm{~kW}$ per 1 $\mathrm{m}^{2}$ per annum. In 2010, the KazPV project was launched, the main goal whereof is to create a complete vertically integrated manufacturing of photoelectric modules on the basis of Kazakh silicon. The Kaz Silicon Company mines silicon the town of Ushtobe (Amlaty Region). The Kazakhstan Solar Silicon company processes the raw material and manufactures silicon cells in Ust-Kamenogorsk. The Astana Solar Company (located in Astana) is responsible for the final stage of manufacturing - the assembly of the photoelectric modules. In late 2012, the first stage of the Otar solar power plant with a capacity of $504 \mathrm{~kW}$ (designed capacity - $7 \mathrm{MW}$ ) was commissioned in the Korday District, Jambyl Region. The Kapshagai solar power plant with a capacity of 2 MW was launched on December 20, 2013 in the town of Kapshagai, Almaty Region. The project was realized by the Samruk-Green Energy Company, a subsidiary of Samruk-Energo JSC. The Nazarbayev University Center of Energy Research is implementing several projects in the field of renewable power engineering and power efficiency:

- "Third-Generation Solar Photocells";

- "Photon-Crystal Light Concentrators for the Collection and Transfer of Electromagnetic Energy";

- "Research and Development of Technologies for Renewable Power Engineering and Intelligent Networks for Use in the Republic of Kazakhstan".

Since Kazakhstan is mostly an agrarian country, it is reasonable to develop bio-power engineering extensively here. The potential of agricultural waste processing in Kazakhstan is estimated at 35 billion $\mathrm{kWh}$ and $44 \mathrm{Gcal}$ of heat energy per annum. The production of biogas, which can be done in devices of various sizes, is especially efficient in agricultural complexes that are able to implement a full ecological cycle. Biogas is used in lighting, heating, cooking, mechanism, transport, and power generation actuation. Kazakhstan has more than 10 million hectares of forests, which amounts to $4 \%$ of the total area of the country, 4700 thousand hectares of which are covered with sexual. In 2013, the forest harvesting output in the country was about 3 million $\mathrm{m}^{3}$ per annum. The amount of wood waste that is generated at felling areas and woodworking facilities and the amount of wood that is used as firewood is about 1.3 million $\mathrm{m}^{3}$ or 1 million tons. Thus, the energy potential of wood waste is more than 200 thousand tons of oil equivalents.

Cereal crop straw is the most important renewable energy resource in the Republic of Kazakhstan. In 2013, the output of straw was almost 37 million tons. If one were to assume that $20 \%$ of this output could be used for energy purposes, then the output of energy would exceed $87 \mathrm{GW}$. The most promising projects that involve the use of biomass for energy purposes are related to straw. Another promising direction is the use of biogas, which is produced from the waste of farms and poultry farms, by agricultural companies for their own needs. Kazakhstan has a considerable livestock of cattle and poultry. The potential of methane production from the waste of cattle is more than 85 thousand tons or more than 52 thousand tons of oil equivalents. The potential of methane production from utilities wastewater treatment is about 3 thousand tons or almost 1800 tons of oil equivalents.

Bio-power engineering is an actively growing sector of the world economy that uses biomass, i.e. energy sources of plant origin that accumulate solar energy in the form of hydrocarbons, instead of conventional hydrocarbon raw materials (coal, oil, and gas). Nowadays, biomass satisfies $15 \%$ on average of the total consumption of primary energy sources in the world: $48 \%$ in developing countries and $2-3 \%$ on average in industrially developed countries $(3.2 \%$ in the USA, $6 \%$ in Denmark, $12 \%$ in Austria, $18 \%$ in Sweden, $23 \%$ in Finland). The growth rate of production of various biofuels is about $40 \%$ per annum in the world.

A considerable advantage of biogas plants is that they simultaneously act as treatment facilities that reduce the bacterial and chemical contamination of the soil, water, and air. When compared to small hydroelectric, wind, and solar power stations, which are passively eco-friendly, i.e. they use environmentally friendly energy sources, biogas plants are actively "eco-friendly", because they remove the environmental hazard of products that are used as a primary energy source. The use of biomass energy has many unique properties that give environmental advantages. It can alleviate the problem of climate change, reduce the frequency of acid rains, soil erosion, water pollution, and the load on domestic solid waste dumps, provide an environment for wild animals, and help maintain healthy living conditions for forests through better management.

About 60 varieties of biogas production technologies are currently used and developed in the world. The most widespread technique is anaerobic fermentation in digesters or anaerobic columns. Part of the energy that is produced during the recycling of biogas is used to maintain the process (up to 15-20\% in wintertime). In countries with a hot climate, there is no need to heat the digester. Bacteria transform the biomass into methane at a temperature from $25^{\circ} \mathrm{C}$ to $70^{\circ} \mathrm{C}$. Biogas plants can be installed at treatment facilities at farms, poultry farms, alcohol plants, sugar refineries, and meatpacking plants.

The advantages of biofuel produced via waste recycling include its accessibility, especially for people who live in rural areas and can organize a closed production cycle at farms and its rich, virtually inexhaustible, and self-replenishing raw material stock. Biogas plants offer one of the most 
practical solutions to the issue that concerns environmentalists: what to do with trash? Organic trash recycling and the production of highly effective fertilizers with byproducts (biofuel and carbon dioxide, which is useful at farms, and pure water if the plant is equipped with special filters) is virtually beyond the competition of other track recycling facilities.

Despite the environmental friendliness of biogas, this type of fuel still does not rule out the greenhouse effect. Biogas burning minimizes hazardous emissions into the atmosphere, but does not remove them entirely. The second problem of biogas is the fact that it is easy to obtain only in rural areas that are abundant with raw materials that are used in its production. This problem is organizational and solvable by proper development of the infrastructure; however, while as long as biogas plants remain an exception to the rule, rather than an everyday standard, the problem of an underdeveloped production complex remains relevant. Although industrial plants are relatively inexpensive, not any farmer can afford small individual biogas plants, which is why they take bank loans to purchase them. In order to pay back the loan, farmers grow energy crops that exhaust the land, which, in turn, has a negative effect on land ecology.

Unfortunately, biogas production technologies are still imperfect; however, state grants and an active stance of citizens enable these technologies to develop rapidly. After the flaws are removed, production costs are reduced, and production efficiency is improved, biogas and biogas plants will play a major role in the normalization of the deteriorating environmental situation on the planet, including global warming.

Nowadays, forestry, agriculture, and housing and utility waste is the main raw material for the generation of electric and heat energy from biomass. Furthermore, an insignificant part of agricultural crops - sugar, cereal, vegetable oil - are used as raw materials in the production of liquid biofuel. Nowadays, the amount of biomass-generated energy that is consumed worldwide is about $50 \mathrm{EJ}$, which constitutes about $10-15 \%$ of the worldwide annual consumption of primary energy. This usually is traditional biomass for cooking and heating. However, there is considerable potential for expanding the area of application of biomass in the large amount of unutilized residue and waste. The use of ordinary crops for power generation can also be expanded if the demand for food and available unoccupied areas are determined properly. In the mid-term, cellulose-fiber crops (both grass and wood) will be obtainable on marginal, degraded, and excess agricultural lands; said crops can potentially provide a considerable amount of biomass.

In the long run, water-based biomass (seaweed) can also make a significant contribution. Considering the wide range of raw materials, the technical potential of biomass is estimated at more than 1500 JK/year by 2050, although current trends and scenarios of biomass production indicate that the annual potential is 200-500 EJ/year (with the exception of water-based biomass).

The long-term potential of energy crop farming largely depends:

- on the availability of unoccupied land, which depends on the development of the food sector (growth of the demand for food and increase in the yield of agricultural crops) and factors that limit access to land, such as water and environmental protection;

- on the choice of energy crop that determine the output of biomass and can be grown on unoccupied land;

- on other factors that can affect the potential of biomass include the effect of biotechnologies, such as genetically modified organisms, the availability of water, and consequences of climate change.

\section{The use of biomass depends on several factors:}

- the cost of biomass production - \$4 per $1 \mathrm{GJ}$ is often regarded as the upper limit, when bioenergy engineering can become widespread in all sectors;

- logistics - similar to all agricultural crops, energy crops and waste require an appropriate chain of supply and infrastructure;

- resources and environmental protection production of raw materials for biomass can have both positive and negative effects on the environment (availability and quality of water, quality of soil, and biodiversity). It is necessary to take into consideration the laws that could restrict or stimulate existing practices (for instance, environmental laws, sustainability standards, etc.).

Drivers of wider use of bioenergy (for instance, state priorities in the field of renewable energy sources) can increase the demand for biomass, which will lead to competition for land that is currently being used to produce food. This will require governmental intervention, with a view to regulating the development of bioenergy engineering and land utilization and ensuring consistent demand and production. The development of an appropriate policy will require an understanding of complex issues and international cooperation, with a view to taking measures to ensure consistent global production of biomass.

In order to use the bioenergy potential, long-term efforts should be aimed at increasing the output of biomass, modernizing agriculture, directly increased the global output of food products, thus producing more resources for biomass. This can be achieved by improving technologies and ensuring sustainable agricultural management. In addition, it is necessary to reward and stimulate the sustainable use of residue and waste for biomass production, which is a limited or zero environmental hazard.

Power supply to autonomous economic entities nowadays uses advanced wind farms. For instance, 
in the USA, the Urban Green Energy (UGE) Company has recently offered its new vertical wind turbine Vision Air. The new concept is an advancement of the previous series of $4 \mathrm{~K}$ turbines that were supplied for the equipment of autonomous charging stations of Watt Station electric cars. When compared to previous models, the major change is the structure of blades, which increased the effectiveness of power generation at low wind speeds. The new blades will be manufactured based on a technique of molding of resin-saturated components. According to the experts of the company, the service life of a Vision Air wind turbine is at least 20 years. The company has received several certificates of quality and safety from third parties, as well as certificates of conformance to multiple international standards, which is enough to start the manufacturing of turbines. Nowadays, the turbine, the first in its class, is undergoing tests in the USA, with a view to receiving the IEC-61400 certificate.

The new turbine is set to become the standard option for the main hybrid energy concepts of the company, which is intended for power supply to autonomous business and telecommunication objects. Vision Air is capable of integrating with the Seamless Grid management system, which the UGE Company developed specially for combining wind turbines and solar photoelectric panels in hybrid plants. The system allows for remote monitoring and control and provides additional security functions that improve the reliability and durability of electric plants.

The turbine is 5.2 meters tall and requires an area of $16.6 \mathrm{~m}^{2}$ to be installed. At a wind speed of $5.5 \mathrm{~m} / \mathrm{s}$, the annual output of Vision Air is $3600 \mathrm{kWh}$. Rated wind speed is $11 \mathrm{~m} / \mathrm{s}$, while maximum wind speed is $30 \mathrm{~m} / \mathrm{s}$. At that, the turbine is capable of withstanding winds up to $50 \mathrm{~m} / \mathrm{s}$. Furthermore, the new turbine is notable for the low level of noise it generates. At a wind speed of $12 \mathrm{~m} / \mathrm{s}$, the noise level is only $38 \mathrm{~dB}$. The UGE Company assumes that Vision Air's ability to operate effectively at low wind speeds will ultimately make it more effective. This energy complex can be used to supply power to remote agricultural objects.

A promising area in the development of renewable power engineering the rural areas is the use of hybrid (combined) energy complexes.

\section{Discussion}

The world experience of utilization of renewable energy sources shows that using only a single type of renewable energy source does not always provide reliable and uninterrupted power supply due to the physical features of the renewable energy sources themselves (Dinica, 2006). Power supply to autonomous consumers with the use of renewable energy sources is usually organized by using a combination of different types of primary and secondary energy within the framework of so-called energy complexes. These complexes generally include power plants that are based on renewable energy sources, diesel (gas) power plants, and various energy accumulation systems. The system of design planning of the parameters and modes of energy complexes based on renewable energy sources is complicated, which requires well developed informational, mathematical, and software support to solve the problem of financial and economic rationalization of the designed energy complexes in Kazakhstan, where the current state of development of the energy sector is characterized by many uncertainties and risks that affect the efficiency of energy complexes based on renewable energy sources. An autonomous energy complex should be capable of ensuring reliable supply of electricity and heat to the consumer.

An example of the use of new technologies for alternative electric energy generation is a scheme that combines a "green" electric power plant based on renewable energy sources and a diesel (gas) generator as a reserve. The "green" or, in other words, hybrid power plant operates in sunny or windy weather and charges accumulator batteries or supplying power to the consumer. As soon as the hybrid power plant ceases to generate the necessary amount of energy, the diesel generation kicks in and compensates for the shortage. Such a power supply scheme has the following advantages: reliable power supply system, fuel saving, increased service life of the diesel generation, and environmental friendliness. Such "green" power plants have not yet become widespread in Kazakhstan.

Hybrid power plants can be used to create multifunctional energy complexes. Their main functions are uninterrupted supply of set amounts of electric power to the consumer and generation of a maximum amount of energy from two or more alternative energy sources. Alternative energy sources can include a solar electric generation or wind electric generation. A diesel generator and a reserve generator (accumulator) can serve as additional generators. They are convenient to install at farms or power consumers that are located far from power grids. If used year-round, these complexes cut the consumption of liquid fuel by four-six times. A combined power plant is a complicated complex. It requires an optimization of parameters of separate elements of the complex, their operating modes, and means of control of these modes. Reliable operation of such power plants requires modern management system automation based on computers.

Conditions for determining the optimum are not always constant and can vary considerably with time; this includes the cost of equipment, its type, consumer load, etc. Therefore, recommendations and maps become irrelevant over time, while for different equipment and consumers, the results of optimization can differ significantly. The developed software complex takes into account multiple factors and peculiarities of the present and produces reliable results that are relevant for the current operating conditions of combined systems of autonomous power supply based on renewable 
energy sources. For instance, the studies of various accumulator batteries shows that a new type of battery was promising - lithium iron phosphate batteries $\left(\mathrm{LiFePO}_{4}\right)$. Their use instead of conventional lead-acid accumulator batteries reduces the prime cost of electric power when supplying it to the consumer via combined systems of autonomous power supply based on renewable energy sources for the examined five geographic locations by up to $20 \%$ (by $17 \%$ on average). Energy effectiveness is increased by using a special design structure that is based on a modern component base and coordinating the processes of electric energy generation and consumption. The results of a theoretical simulation of the operation of combined systems of autonomous power supply based on renewable energy sources by the example of five geographic locations showed that an increase in the voltage directly at the output of the generators before the inverter input reduces the loss of electric power during transformation by up to $16 \%$ (by $13 \%$ on average). By running on increased voltage, the generator also reduces current loss in the system, thus additionally increasing the general energy conversion efficiency. In addition, the division of consumers into groups enables a reasonable distribution of the load and increasing the volume of "direct" consumption of energy, which, in turn, reduces the amount of energy that is compensated via accumulators and, consequently, the associated energy loss, as well. This function can be realized more efficiently by estimating the energy output from renewable energy sources thanks to the ability to plan the operation of the system for an upcoming time period.

The choice of primary sources for combined systems of autonomous power supply based on renewable energy sources was rationalized by the improvement of the reliability of power supply to the consumer, which can be classified as a generalized efficiency characteristic.

Improvements in technological efficiency is associated with the development of the logic and algorithms of a specialized two-level automated management and monitoring system within the framework of the centralized management principle with regard to the peculiarities of renewable energy sources and consists in the execution of more efficient system functioning processes and expansion of its functional capacities. This allows implementing new principles in the power supply system, which corresponds with the Smart Grids concept, thus enabling combined systems of autonomous power supply based on renewable energy sources to become active participants of distributed power engineering in the future. Technologies such as Prointek, Switched Ethernet, Foundation Fieldbus, Profibus, ASI, Device Net, etc. are widely used by both suppliers and users of systems. Nowadays, it is certain that most automation systems in the power industry have different service packages that are specific for the industry.
The proposed complex approaches to improving the efficiency of combined systems of autonomous power supply based on renewable energy sources will bring the power supply systems that are used in agriculture in the Republic of Kazakhstan to a new level of quality.

An important factor for the development of alternative power engineering in Kazakhstan is the training of skilled personnel, which is performed under special programs. Specialized programs investigate various subjects and issues related to power engineering, resources, and raw materials nuclear power engineering, solar power engineering, and renewable energy resources. These programs include studies in nuclear physics, thermodynamics, material science, design and construction of nuclear power plants, renewable energy sources, heating systems that run on solar power, design and construction of solar power plants, and management in this field. Training programs that cover environmentally friendly energy sources train specialists that are able to implement cutting-edge technologies to improve the energy efficiency of existing systems and reduce their impact on the environment. Other programs combine the environmental, social, and governmental aspects, which are important when dealing with issues related to the development of power engineering and resource utilization. Training programs that cover this area of power engineering make a considerable contribution to the solution of problems related to the ever-growing need of the country's population for energy resources.

The power supply problem is especially evident in the rural areas of the South Kazakhstan Region. The South Kazakhstan Region is located in a desert area and its terrain is mostly flat. In the north lies the Betpak-Dala clay desert; south of Chu River lies the Muyunkum Desert. In the southwest - the Kyzylkum Desert and the Shardara steppe. In the far south the Mirzashol steppe. In its central part - the Karatau Mountains; in the southeast - the Talas Ala-Too, Qarschantau, and Ogem ranges. Vast pastures, fertile soil, and abundant sunshine create all the necessary prerequisites for the development of various branches of agriculture, primarily irrigated farming and pasture animal husbandry.

The South Kazakhstan Region is a region that is experiencing power shortages. The amount of power that the region produces itself covers $45-47 \%$ of the demand of said region. The average daily power shortage is $45-47 \%$ in wintertime and $60 \%$ in summertime. The average daily consumption of electric power is $430-470 \mathrm{MW}$ in wintertime and 330-350 MW in summertime. The power shortage is compensated for by power supplies from the northern regions and the Jambylstate district power plant. The main consumer of power in the region is its citizens, whose consumption constitutes $60 \%$ of the total power consumption of the region.

In this region, electric power is distributed by the OntustikZharyk Transit LLP regional power company. The total length of overhead power lines in 
the region is $26,107.9 \mathrm{~km}$, while the number of electric power substations and transformers is 7273 . OntustikZharyk Transit LLP controls $88.9 \%$ of networks and equipment $(22,941.3 \mathrm{~km}$ of power lines and 5639 units of equipment). The wear of power lines and equipment is $59.5 \% .1059 .3 \mathrm{~km}$ of power lines and 698 substations and transformers are privately owned.

In recent years, the industry has begun taking measures to improve energy efficiency and cut energy losses. Automated commercial power accounting systems are being implemented, measures are taken to reconstruct and modernize networks and equipment. In 2015, 5.9 billion tenge were allocated from the national and regional budgets to the construction of 21 power supply facilities in Shymkent, Turkestan, and Kentau, and in the Tole Bi, Saryagash, and Otyrar Districts. Electric power networks and equipment in the region is being developed according to the "Plan for the Development of $11035 \mathrm{kV}$ Electric Power Distribution Networks in the South Kazakhstan Region and Shymkent city 2015-2020", which was developed in 2007 by the Kazselenergoproekt Institute LLP.

Out of the 929 settlements in the region, 913 are connected to the centralized electric system. Sixteen settlements, which are pastures for animal husbandry, are not connected to the centralized power supply system. They run on power that is generated by autonomous sources (gas, diesel, and wind power plants).

The region hosts the Kelesgidrostroy small hydro power plant with a capacity of $1.32 \mathrm{MW}$. In order to further develop this area, 28 projects have been launched, including the construction of nine small hydro power plants with a total capacity of $24.8 \mathrm{MW}$, five wind farms with a capacity of $310 \mathrm{MW}$, and 14 solar power plants with a capacity of 419 MW. The projects are being implemented in all towns and districts of the region; land plots have been allocated for research and development of alternative electric power stations.

The region has a considerable wind-energy potential. According to the United Nations Development Program, it is possible to construct wind farms with a capacity of $41.2 \mathrm{MW}$ in the territory of the Tulkibas and Kazygurt Districts. In the Baydibek District (Zhuzimdik village), the Kazakhstan Utility Systems LLP company is developing a technological and economic rationalization for the construction of a wind farm with a capacity of $40 \mathrm{MW}$; a $100 \mathrm{~m}$ tall tower has already been installed. The project is set to finish in 2016-2017.

The South Kazakhstan Region has well developed animal husbandry and crop farming. As shown in Fig. 2 , the cattle livestock in the South Kazakhstan Region constitutes $14 \%$ of the total cattle livestock that is bred in the 16 regions of the Republic of Kazakhstan.

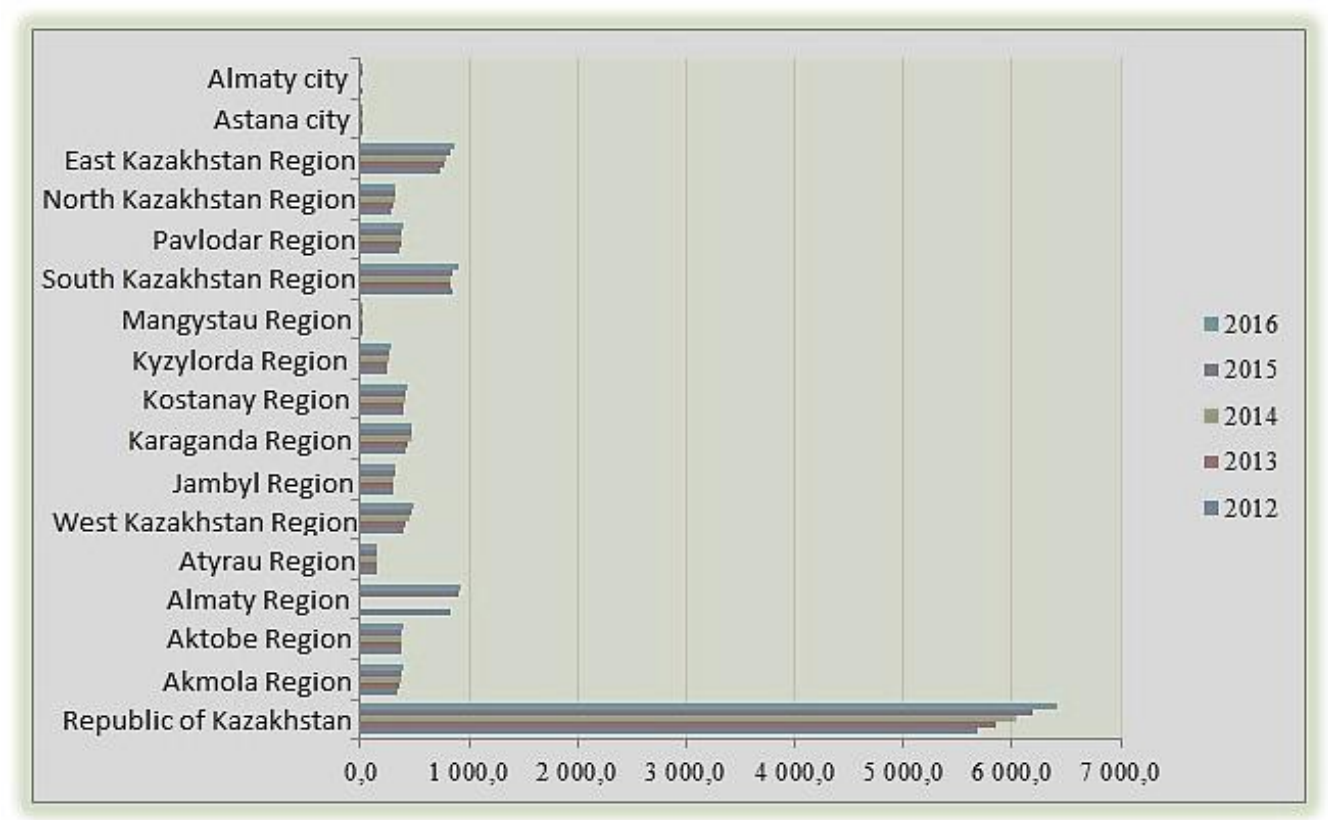

Fig. 2: Head count of cattle in the Republic of Kazakhstan, thousand units

In our opinion, bio-power engineering can achieve the best development and relevance in rural areas in such a region as the South Kazakhstan Region, which is experiencing power shortages. This means that it is efficient to produce electric power for the needs of agriculture and the local population by recycling farming and animal husbandry waste. For instance, 1 ton of manure can produce $340 \mathrm{~m}^{3}$ of biogas via anaerobic fermentation in optimal conditions; in terms of one cattle unit, this is $2.5 \mathrm{~m}^{3}$ per day or $900 \mathrm{~m}^{3}$ per annum. The estimation of the benzene energy equivalent of such an amount of biogas shows that one caw can "produce" energy in an amount that is equivalent to $600 \mathrm{~L}$ of benzene per annum. At the same time, fermentation deodorizes and deworms manure, reduces the germinating capacity of weeds, and transforms organic fertilizers into their mineral form. In order to recalculate the amount of biogas that can be generated by poultry farms into that, which can be generated by animal 
husbandry, one can use the following ratio: $1 \mathrm{cow}=$ 250 chickens. The amount of biogas that is generated in a $5000 \mathrm{~m}^{3}$ digester is enough to power a $200 \mathrm{~kW}$ generator. Biogas production is profitable and preferable for electric and heat power generation with constantly available raw material (waste of animal husbandry, crop growing, etc.). Biogas can be produced in machines of different sizes, but it is especially effective in agricultural complexes that can implement a full ecological cycle. Biogas is also used in lighting, heating, cooking, and actuation of mechanisms that are used in animal husbandry and crop growing.

In addition, in the rural areas of the South Kazakhstan Region, it is efficient to use geothermal energy, i.e. electric and heat power that is generated by energy from the entrails of the earth. Detection of geothermal steam fields in Kazakhstan is currently insufficiently active. Exceptions are the steam fields that are located in Kaplanbek village (near Shymkent) and near Almaty. The water temperature in the Kaplanbek steam field is $80^{\circ} \mathrm{C}$, which allows using it to supply heat to living quarters that are used in animal husbandry and crop growing.

In order to develop nonconventional power engineering, the government supports companies that develop alternative power engineering technologies. The Law on Renewable Energy Sources and certain other pieces of legislation that change the system of procurement of electric power from entities that use renewable energy sources entered into force in January of 2014. In order to develop the use of renewable energy sources, the government offers a wide range of advantages and privileges to companies that work in this field, including:

- it is not obligatory to have a license to produce renewable energy sources;

- guaranteed buyout;

- predictable and long-term tariffs;

- distribution of land for objects that use renewable energy sources;

- investment preferences;

- taxation concessions.

The acquisition and operation of bio-plants to generate electric power, the development of geothermal power engineering, the use of advanced "energy-saving" technologies to grow animals and crops, manufacturing of highly automated equipment, and training of specialists for managing "smart" animal husbandry and crop growing complexes, when combined with governmental support, will enable agriculture to achieve a higher level of economic and power development. The design, construction, and operation of alternative power plants and complexes thereof (both wind and solar) in the South Kazakhstan Region and other regions of Kazakhstan, thanks to innovative technologies and training of next-generation power engineers will provide a significant boost to the improvement of rural power engineering by increasing the percentage of alternative energy sources in the total amount of power consumption by agriculture to $50 \%$ by 2050 , increasing the growth rate of the output of agriculture by $30 \%$, and improving the environmental safety of power engineering for rural areas.

\section{Conclusion}

When making decisions regarding the use of renewable energy sources to supply power to territories, remote industrial and nonindustrial facilities, it is necessary to take into consideration not only its effect for the interested parties, but also the effect for society in general (socio-ethical effect), which includes the abandonment of technologies that have a negative impact on the environment, generation of additional budgetary revenues, and creation of jobs.

The main directions for the development of rural power engineering are as follows:

- implementation of renewable energy sources (wind, solar, small and mini-hydro power plants, bio-plants, geothermal plants, etc.);

- low energy consumption of the economy, which is achieved by taking measures to ensure energy efficiency and energy saving;

- diversification of power supply, which is achieved by decentralizing powerlines and organizing local hybrid power plants;

- implementation of efficient network-based electric and heat power supply on the basis of renewable energy sources;

- expansion of production and utilization of new fuels that are obtained from different types of biomass.

The factors that affect the measures in the field of power engineering include:

- Power tariffs, funding of research, and changes in the structure of power engineering. These are the key uncertainty factors that have a considerable impact on the future of the energy sector

- Strategies for overcoming the electric power shortage based on the needs that stem from the key factors in power engineering and the development of energy markets

- The modernization of power engineering with the use of cutting-edge technologies and funding of research has been determined as a riskreducing strategy for the future

- Availability of skilled specialists in production and sales of alternative power.

- Infrastructure of rural power engineering (informational, consulting, etc.)

\section{References}

Cook DJ (2005). Prediction algorithms for smart environments. In: Lewis FL (Ed.), Smart environments: Technologies, protocols, 
and applications: 175-192. John Wiley and Sons, Hoboken, New Jersey, USA.

De Jager D, Rathmann M, Klessmann C, Coenraads R, Colamonico C, and Buttazzoni M (2008). Policy instrument design to reduce financing costs in renewable energy technology projects. PECSNL062979, International Energy Agency Implementing Agreement on Renewable Energy Technology Deployment, Utrecht, The Netherlands.

Dinica V (2006). Support systems for the diffusion of renewable energy technologies-an investor perspective. Energy Policy, 34(4): 461-480.

Farrell J (2009). Feed-in tariffs in America. Heinrich Böll Foundation North, New Rules Project, Minneapolis, Minnesota, USA.

Ferroukhi R, Doukas H, Androulaki S, Menichetti E, Masini A, and Khalid A (2013). EU-GCC renewable energy policy cooperation: Exploring opportunities. GRD GUlf Papers, Kuwait.

Grechukhina IA and Kiryushin PA (2015). Renewable energy sources as a factor of the transformation of global power engineering. Naukovedenie Internet Journal. 7(6): 240-249.

Jenner S, Groba F, and Indvik J (2013). Assessing the strength and effectiveness of renewable electricity feed-in tariffs in European Union countries. Energy Policy, 52: 385-401.

Kateneva J (2016). Ученые: мир может полностью перейти на ВИЭ к 2050 году [Scientists: The world can switch to renewable energy sources fully by 2050]. Available online at: https://teknoblog.ru/2016/12/19/72841

Kiushkina RV (2016). Анализ мировых трендов развития энергетики в прогнозной перспективе [Analysis of global trends in the development of power engineering in the predictable future]. Молодой ученый [Young Scientist], 26: $42-45$.

McCollum DL, Krey V, and Riahi K (2011). An integrated approach to energy sustainability. Nature Climate Change, 1(9): 428429.

Mitchell C, Sawin J, Pokharel GR, Kammen DM, Wang Z, Fifita S, and Blanco RT (2011). Policy, financing and implementation. IPCC Special Report on Renewable Energy Sources and Climate Change Mitigation, Cambridge University Press, Cambridge, UK.

MNERKCS (2017). Statistics. Ministry of National Economy of the Republic of Kazakhstan Committee on Statistics, Kazakhstan. Available online at: https://stat.gov.kz

Rutovitz J and Harris SM (2012). Calculating global energy sector jobs: 2012 methodology. Institute for Sustainable Futures, University of Technology, Sydney, Australia.

Sidorovich VA (2015). Mirovaya energeticheskaya revolyutsiya [The global energy revolution]. Alpina Publ, Moscow, Russia.

Verbruggen A and Lauber V (2012). Assessing the performance of renewable electricity support instruments. Energy policy, 45 : 635-644. 